\title{
Biodegradable film based on taro starch with variations of duck bone gelatin concentration: physical and barrier properties
}

\section{Trias Ayu Laksanawati, Muhammad Habbib Khirzin, Maghfirotul Amaniyah}

\author{
State Polytechnic of Banyuwangi, Banyuwangi, Indonesia
}

\section{Keywords:}

Bifilm

Starch

Gelatin

Physical

Barrier

\section{Article history:}

Received

18.09.2021

Received in

revised form

01.12.2021

Accepted

30.12 .2021

\section{Corresponding} author:

Trias Ayu

Laksanawati

E-mail:

trias@

poliwangi.ac.id

DOI:

$10.24263 / 2304-$

974X-2021-10-

4-9

\section{Abstract}

Introduction. This study aims to improve the physical properties of biodegradable films based on taro starch added with duck bone gelatin and glycerol as a plasticizer by using the solution casting method.

Materials and methods. A non-factorial completely randomized design (CRD) with ANOVA was used, followed by the DUNCAN test to determine the effect of different treatments. Various concentrations of duck bone gelatin were used, including $0,5,15,25$ and $35 \%$ of the total weight of solids (taro starch and duck bone gelatin). The functional groups of biodegradable films were analyzed using Fourier Transport Infrared (FTIR). The morphological structure of the product was studied using Scanning Electron Microscope (SEM).

Results and discussion. The parameters observed included the water vapor transmission rate test, which resulted in a value of $0.465-$ $0.529 \mathrm{~g} / \mathrm{m}^{2}$.hour. The highest water vapor transmission rate was at a concentration of $35 \%$ duck bone gelatin of $0.529 \mathrm{~g} / \mathrm{m}^{2}$ hour. The factor that affects the value of the water vapor transmission rate is the chemical nature of the material polymer. Water absorption was $85.17-$ $40.47 \%$, and the highest water absorption was at a concentration of $0 \%$ duck bone gelatin. The percentage of water absorption is used to assess the value of the water resistance of the resulting film. Water solubility was $31.08-64.60 \%$. The highest water solubility value was at a concentration of $35 \%$ duck bone gelatin of $64.60 \%$ because the addition of duck bone gelatin can reduce the intermolecular forces of the film and increase water activity so that free water molecules can occupy the matrix in the film.

The FTIR spectrum for biodegradable film products showed a peak wavenumber at $3600-3000 \mathrm{~cm}^{-1}$, indicating the presence of N-H and O$\mathrm{H}$ groups. The presence of $\mathrm{N}-\mathrm{H}$ and $\mathrm{O}-\mathrm{H}$ groups in biodegradable films can help the degradation process because they have hydrophilic properties that enable water molecules to access and enter the film matrix.

The results of SEM analysis showed that the taro starch film with the addition of duck bone gelatin produced a homogeneous and flexible biodegradable film with compact structure.

Conclusions. The addition of duck bone gelatin had an insignificant effect on the water vapor transmission rate but a very significant effect on water solubility and a significant effect on water absorption. 


\section{Introduction}

Plastic is a common packaging material but is not decomposable (Muin et al., 2017). It has advantages, including practical, transparent, flexible, economical, strong, and multifunctional. This is what causes plastic packaging to be widely used by the community, resulting in increasing waste. This can cause environmental damage. Therefore, an alternative for making biodegradable plastics, called biodegradable films, is needed. Biodegradable film is a biodegradable and environmentally friendly plastic (Aripin et al., 2017). The main ingredients for making biodegradable films come from cellulose, chitosan, starch, protein, or a combination of components (Asngad et al., 2018). Among these natural polymers, starch is a polysaccharide that is widely used as a material for making biodegradable films. It is one type of carbohydrate that is found in nature, one of which is from plant body parts such as seeds, roots, stems, and cereals (Aryanti et al., 2017). Starch contains compact-structure amylose and amylopectin (Udjiana et al., 2019). Different levels of amylose and amylopectin can affect film formation (Rosseto et al., 2019). Starch from taro tubers was used because it has a starch content of $80 \%$, which is greater than corn starch content of $71.3 \%$ and cassava starch content of $72.17 \%$ (Rahmawati et al., 2012); besides, taro starch is a natural renewable material. The use of starch in biodegradable films has the advantages of being easy to decompose (biodegradation), easy to form films (plastic), easy to obtain (Winarti et al., 2012), and not easily penetrated by water vapor (Aripin et al., 2017) However, starch also has drawbacks, including low mechanical properties and being easy to dissolve in water (Bani, 2019). Other additives are needed to improve these, one of which is duck bone gelatin to reduce the stiffness of the polymer and its hydrophilic properties to water (Resalina et al., 2013). Taro starch and duck bone gelatin is renewable in making biodegradable films. Gelatin added to the biodegradable film will provide flexural and elastic properties (Illing et al., 2017). Gelatin can also increase its solubility in water to facilitate the degradation process (Kumar et al., 2019).

Biodegradable film based on gelatin is usually very good as a barrier to oxygen, carbon dioxide, and some aromatic compounds, and has excellent mechanical properties (mechanical strength of the film) and barrier properties (the ability to inhibit the entry and exit of certain substances through the film) (Jagadeesh et al., 2016). In addition, gelatin also basically has good barrier properties against UV rays due to the presence of aromatic amino acids (the structure resembles a ring) which is able to absorb UV light, so that it can prevent oxidation in food products wrapped in plastic from the protein. Mixing two different polymers, such as gelatin and polysaccharides, proteins and lipids, polysaccharides and lipids or synthetic polymers and natural polymers aims to improve the biodegradable film properties.

Gelatin is an animal protein product from the hydrolysis of collagen (Chaves da Silva et al., 2018). It is widely used by the food and non-food industries. The food industry uses gelatin as an emulsifier, binder, stabilizer, and thickener (Miskah et al., 2010). The non-food industry uses gelatin as an additive for making films or plastics (Puspawati et al., 2017). The raw materials of gelatin come from cow bones, cow skins, pig skins (Santosa et al., 2018), and poultry including ducks, chickens, and birds (Puspawati et al., 2017). Duck bone waste was used as a source for making gelatin. Generally, duck bone waste has not been utilized optimally. Therefore, it is necessary to conduct research on making biodegradable films based on taro starch and duck bone gelatin to produce better physical properties, namely water vapor transmission rate, water solubility, and water absorption.

The aim of research is to improve the physical and barrier properties of biodegradable films based on taro starch added with duck bone gelatin. 


\section{Materials and methods}

\section{Materials}

The main ingredients used were taro tubers and duck bone gelatin obtained from markets and restaurants in Banyuwangi Regency, Indonesia. Sodium hydroxide $(\mathrm{NaOH}$, analytical grade, Merck KGaA, Darmstadt, Germany); hydrochoric acid ( $\mathrm{HCl}$, analytical grade, PT. Smart Lab Indonesia); aquadest (CV. Makmur Sejati, Malang, Indonesia); glycerol (CV. Sahabat Lab, Indonesia). Thermometer, hot plate, magnetic stirrer, food dehydrator, dry box, beaker glass, spatula, desiccator, petri dish, measuring cup, dropper, pot, stove, knife, oven, scale analytics, Fourier Transform Infrared Stresscopy (FTIR), and Scanning Electron Microscope (SEM) were used in research.

\section{Synthesis of Biodegradable Film}

In this study, the biodegradable films of taro starch and duck bone gelatin were made using the solution casting method. Five treatments were used with different concentrations of duck bone gelatin, namely $0,5,15,25$ and $35 \%$ of the total solids weight (taro starch and duck bone gelatin). Taro starch and duck bone gelatin were weighed according to the treatment. Starch was dissolved in $10 \mathrm{ml}$ of distilled water using a hot plate and stirred with a magnetic stirrer at $70{ }^{\circ} \mathrm{C}$ with a speed of $375 \mathrm{rpm}$. Gelatin was also dissolved in the same way as taro starch. The solutions of taro starch and duck bone gelatin were then mixed, heated, stirred, and added with $0.5 \mathrm{ml}$ of glycerol and $5 \mathrm{ml}$ of distilled water. The solution was heated, stirred, and kept a constant temperature of $70{ }^{\circ} \mathrm{C}$. Then, the gelatinization occurred for 40 minutes. The biodegradable film solution was left for 3 minutes. It was poured into a petri dish mold and put in the oven for 24 hours at $60{ }^{\circ} \mathrm{C}$. The sample was left at room temperature after being removed from the mold. The biodegradable film was stored in a zip bag log and given silica gel so that it was not easily damaged and was ready for Fourier Transform Infrared (FTIR), SEM, water vapor transmission rate, water solubility, and water absorption tests.

\section{Fourier Transform Infrared (FTIR)}

Infrared spectra of biodegradable film samples were measured using $\mathrm{KBr}$ pellets with the FTIR Prestige-21 Shimadzu spectrophotometer at wavenumbers between $4000 \mathrm{~cm}^{-1}$ to $400 \mathrm{~cm}^{-1}$. The sample was placed into the set holder and searched with the appropriate spectrum. The result was obtained in the form of spectra of the relationship between wavenumber and intensity. The FTIR spectrum was recorded using a spectrometer at room temperature (Darni et al., 2010).

\section{Water Vapor Transmission Rate Test}

Measurement of the water vapor transmission rate was carried out using a porcelain cup and a glass jar. The porcelain cup was filled with $15 \mathrm{ml}$ of water and covered with a biodegradable film. Then, the porcelain cup was placed in a glass jar containing $30 \mathrm{~g}$ of silica gel with known initial weight and left in a closed glass jar for hours (Sunardi et al., 2019). The water vapor transmission rate test was calculated using the following formula: 


$$
W V T W=\frac{\Delta W}{A \times T}
$$

Remark:

WVTR - water vapor transmission rate; $\Delta \mathrm{W}$ - change in weight of silica gel (gram); A - film area $\left(\mathrm{m}^{2}\right) ; \mathrm{T}$ - storage time interval (hours).

\section{Water Solubility Test}

The cup was cleaned and dried at $100^{\circ} \mathrm{C}$ for 30 minutes. A sample of 1 gram was poured in a cup and placed in an oven at $100{ }^{\circ} \mathrm{C}$ for 30 minutes. The dried sample was weighed as the initial dry weight $\left(\mathrm{W}_{0}\right)$ before being immersed for 24 hours. The sample that was not dissolved in water was removed and dried in an oven for 2 hours at $100{ }^{\circ} \mathrm{C}$; then, it was stored in a desiccator for 20 minutes. The dried sample was weighed as the sample weight after immersion $\left(\mathrm{W}_{1}\right)$ (Gontard et al., 1993). The percentage of water solubility of the sample was calculated by the following formula:

$$
\mathrm{S}=\mathrm{W}_{0} / \mathrm{W}_{1} \times 100 \%
$$

Remark:

$\mathrm{S}$ - Water solubility (\%); $\mathrm{W}_{0}$ - Initial dry weight (gram); $\mathrm{W}_{1}-$ Weight after immersion (gram).

\section{Water Absorbtion Test (Swelling)}

The biodegradable film was cut and weighed the initial weight (W0), then put into a glass beaker containing $15 \mathrm{ml}$ of distilled water for 2 minutes. The sample was removed and there was water on the surface of the plastic then drained using a tissue for 5 minutes, after which it was weighed. Weighing and immersion of the biodegradable film was repeated until the sample had a constant final weight. The water absorption test (swelling) can be calculated using the following formula:

$$
\text { Swelling }=\Delta \mathrm{W} / \mathrm{W}_{0} \times 100 \%
$$

Remark:

$\Delta \mathrm{W}$ - Weight change of biodegradable film (grams);

$\mathrm{W}_{0}$ - Initial weight of biodegradable film (grams).

\section{Morphological Structure Analysis (SEM)}

Observation of the cross sectional morphological structure of biodegradable film products was carried out using Scanning Electron Microscope (SEM) analysis (ZEOL, Germany). Before testing, the samples were placed in a desiccator with $54 \%$ humidity at room temperature. The biodegradable film was prepared by breaking it down in liquid nitrogen and then observing it according to standard procedures. 


\section{Results and discussion}

\section{Fourier Transform Infrared (FTIR) Analysis}

Figure 1 shows the FTIR spectrum of taro starch, duck bone gelatin, glycerol, and biodegradable film.

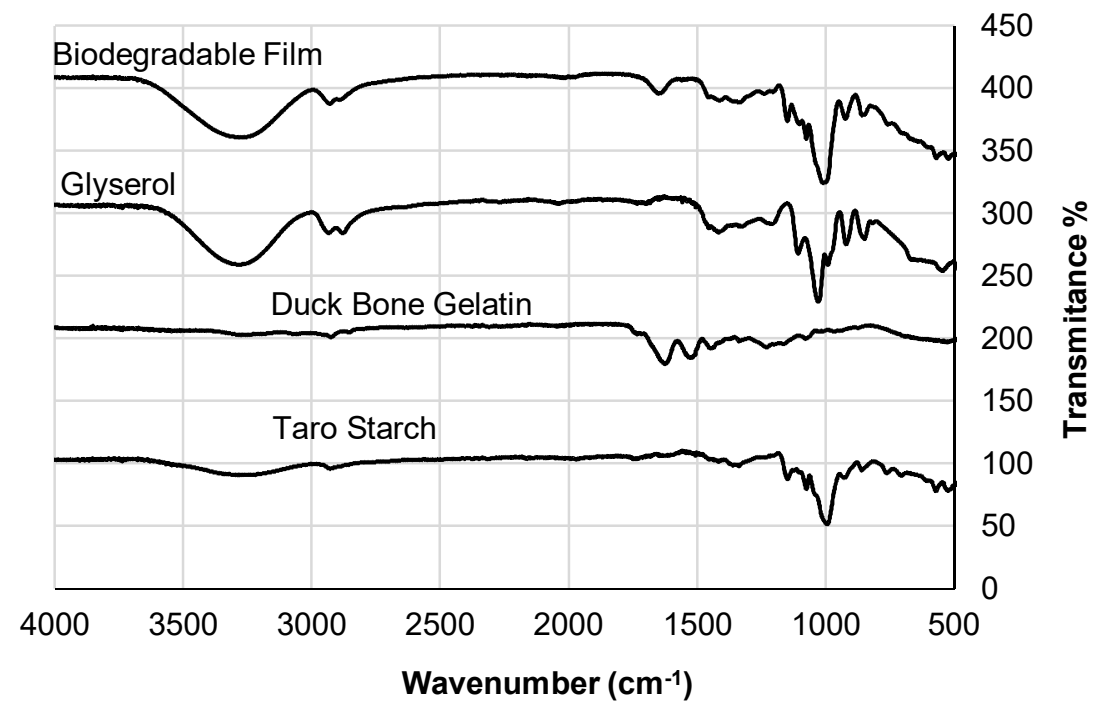

Figure 1. Spectrum FTIR of taro starch, glycerol, duck bone gelatin, and biodegradable film

The biodegradable film was made of three ingredients, namely taro starch, duck bone gelatin, and glycerol; therefore, the functional groups contained in these three ingredients must be present in the biodegradable film. The FTIR spectrum for biodegradable film products showed the peak wavenumber at $3600-3000 \mathrm{~cm}^{-1}$, indicating the presence of $\mathrm{N}-\mathrm{H}$ and $\mathrm{O}-\mathrm{H}$ groups. This causes water to be easily absorbed due to the presence of inter- and intra-molecular hydrogen bonds. Therefore, there is an interaction and molecular solubility between taro starch, duck bone gelatin, and glycerol in biodegradable films (Tongdeesoontorn et al., 2012). The peak wavenumber at $1,589 \mathrm{~cm}^{-1}$ indicated the $\mathrm{C}=\mathrm{C}$ group contained in gelatin (Radiyatullah et al., 2015). The peak wavenumber at $1,468 \mathrm{~cm}^{-1}$ represented the $\mathrm{C}-\mathrm{H}$ group found in starch and glycerol (Iling et al., 2017). The peak wavenumber at $1,350 \mathrm{~cm}^{-1}$ indicated the $\mathrm{C}-\mathrm{N}$ group in gelatin (Kong et al., 2007). The mixture of materials in the biodegradable film showed the functional groups contained in the three constituent materials and can be found in the biodegradable film product. This shows the presence of hydrogen bonds between polymers so that the biodegradable film is still hydrophilic (Aritonang et al., 2020). This FTIR analysis is in line with research (Iling et al., 2017) using sago waste and gelatin materials, showing the presence of functional groups in the form of $\mathrm{C}-\mathrm{H}, \mathrm{O}-\mathrm{H}, \mathrm{C}-\mathrm{O}, \mathrm{C}=\mathrm{O}$, and $\mathrm{N}-\mathrm{H}$. Tongdeesoontorn et al. (2012) stated that the functional groups contained in cassava starch and gelatin in the film had such functional groups as $\mathrm{O}-\mathrm{H}, \mathrm{C}-\mathrm{H}, \mathrm{C}=\mathrm{O}, \mathrm{C}-\mathrm{N}$, and $\mathrm{N}-\mathrm{H}$. The presence of $\mathrm{N}-\mathrm{H}$ and $\mathrm{O}-\mathrm{H}$ groups in biodegradable films can help the degradation process because they have hydrophilic 
properties that enable water molecules to access and enter the film matrix (Aritonang et al., 2020).

\section{Biodegradable Film Water Vapor Transmission Rate Test}

Figure 2 shows that the different concentration of duck bone gelatin has no significant effect $(\mathrm{P}>0.05)$ on the water transmission rate of the biodegradable film.

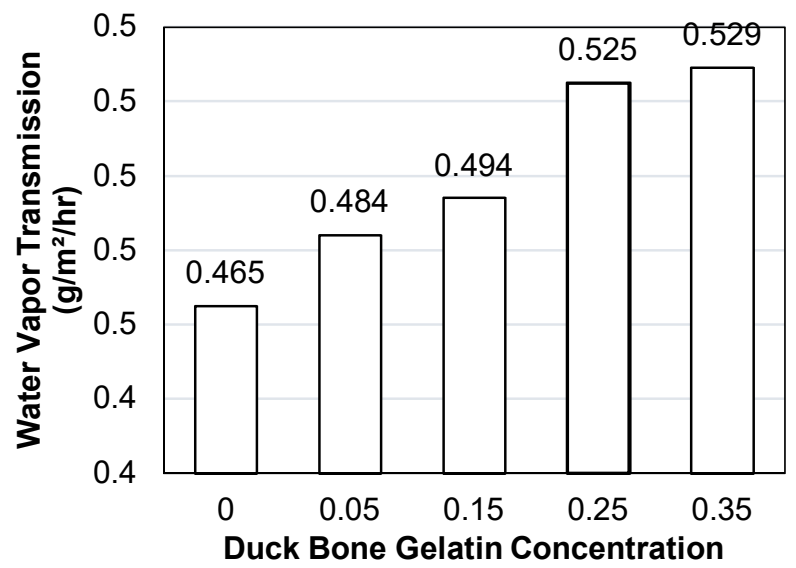

Figure 2. Water vapor transmission rate of biodegradable film

Higher concentration of duck bone gelatin increases the value of the water vapor transmission rate. The highest water vapor transmission rate was $0.529 \mathrm{~g} / \mathrm{m}^{2}$ hour at a concentration of $35 \%$ duck bone gelatin. The factor that affects the value of the water vapor transmission rate is the chemical nature of the material polymer (Budianto et al., 2019). The main ingredients for making biodegradable films in the form of polysaccharides (taro starch) and protein (duck bone gelatin) are polar polymer components that are hydrophilic because they have long hydrogen bonds and can increase the matrix or empty space, thereby accelerating the water vapor transmission rate (Deden et al., 2020). Thicker films will result in less water evaporation (Wijayani et al., 2021). The film structure with many air bubbles can cause water molecules to easily diffuse through the film surface (Widyaningsih et al., 2012). The value of the water vapor transmission rate was low from $0.465 \mathrm{~g} / \mathrm{m}^{2}$ hour to 0.5296 $\mathrm{g} / \mathrm{m}^{2}$ hour and did not exceed the steam transmission rate standard set by the Japanese Industrial Standard (JIS) (1975) for biodegradable film of $7 \mathrm{~g} / \mathrm{m}^{2}$ hour. The result of this study is lower than that of the previous research (Santoso et al., 2020) with low water vapor transmission values ranging from $1.07 \mathrm{~g} / \mathrm{m}^{2}$ hour to $1.60 \mathrm{~g} / \mathrm{m}^{2}$ hour with catfish bone gelatin and breadfruit starch as the main ingredients. The low value of water evaporation makes it difficult for water to penetrate the film so that the product is safer and not easy to damage (Salimah et al., 2016). The higher value of the water vapor transmission rate influenced by duck bone gelatin will result the faster film decomposition because gelatin can be hydrolyzed by adsorbtion of water in the soil and the polymer chains of the film will be broken and easily decomposed (Silviana et al., 2018). 


\section{Biodegradable Film Solubility Test}

Figure 3 shows that the different concentration of duck bone gelatin has a very significant effect $(\mathrm{P}>0.01)$ on the water solubility of the biodegradable film.

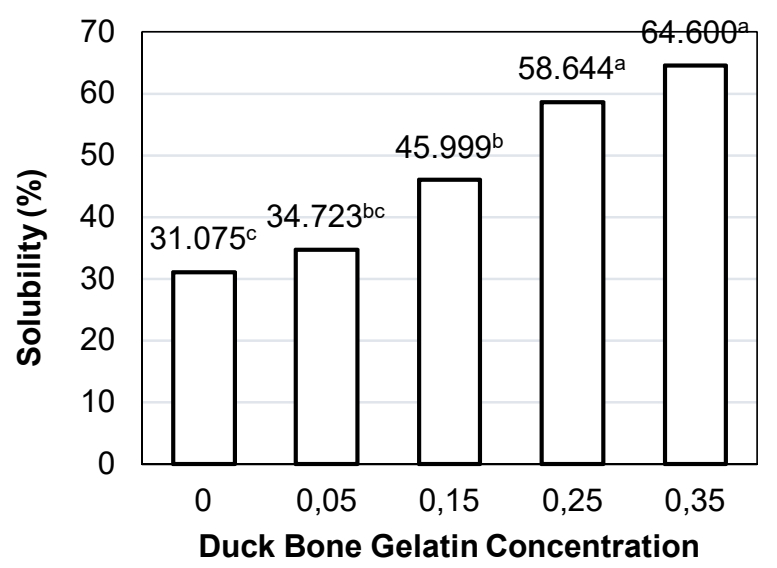

Figure 3. Solubility of biodegradable film

The more concentration of duck bone gelatin increases the value of water solubility. The highest water solubility value was at a concentration of $35 \%$ duck bone gelatin of $64.60 \%$ because the addition of duck bone gelatin can reduce the intermolecular forces of the film and increase water activity so that free water molecules can occupy the matrix in the film (Sutra et al., 2020). Protein-based films (gelatin) have hydrophilic properties due to the presence of polar groups such as hydroxyl, carbonyl, and amino acids that can form hydrogen bonds that can bind to water molecules (Putri, 2018). In addition, gelatin has almost all amino acids except tryptophan (Otoni et al., 2017). The large number of hydrophilic amino acids can increase the affinity of gelatin to water, causing the film to easily bind water molecules (Dhirisma et al., 2014). Therefore, the amount of water that diffuses into the film can cause the breakdown of the film cavity, increasing its water solubility (Wang et al., 2017). This is following Darni et al. (2008) stating that the biodegradable film structure using gelatin has many cavities so that the ability to absorb water is higher.

The solubility value in this study is quite high, from $31.08 \%$ to $64.60 \%$. The solubility value is in line with the finding of Kumar et al. (2020) using corn starch and gelatin, resulting in a solubility value ranging from $20 \%$ to $60 \%$ with increasing concentration of added gelatin. Zulferiyani (2014) reported that the high solubility value could facilitate the biodegradation of the film due to the hydrophilic component because it can absorb water in the soil so that the film is easily broken into polymer units. 


\section{Biodegradable Film Water Absorption Test (Swelling)}

Figure 4 shows that the different concentration of duck bone gelatin has a very significant effect $(\mathrm{P}>0.05)$ on the water absorption of the biodegradable film.

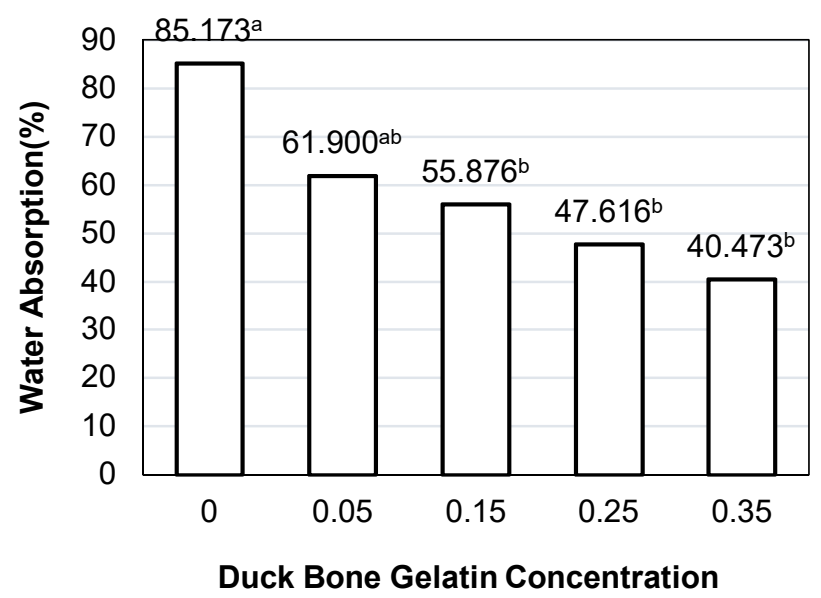

Figure 4. Water absorption (swelling) of biodegradable film

The higher the concentration of duck bone gelatin is, the lower the value of water absorption (swelling) will be. This is because proteins in the form of gelatin have hydrophilic properties due to the presence of polar groups in the form of hydroxyl, carbonyl, and amino acids that can form hydrogen bonds that can bind to water molecules (Putri, 2018). Hydrophilic starch and gelatin can bind to water molecules more quickly so that water easily diffuses, and the film is easy to swell (Kumar et al., 2020). The percentage of water absorption is used to assess the value of the water resistance of the resulting film. This is stated by Iling et al. (2017) that the lower the water absorption value is, the higher the water resistance of the biodegradable film will be. However, this theory is different from the research results. This study found that lower water absorption did not result in higher but lower water resistance values. This is presumably because the increasing concentration of added gelatin can affect the affinity of gelatin. According to Kumar et al. (2019), gelatin can increase the hydrophilicity of water molecules so that it is easier to absorb into the surface of the film. Water resistance will decrease, and solubility will increase. This is also supported by the results of the water solubility test and water content which increase with the higher concentration of duck bone gelatin. The higher solubility causes the film to hold less water so that the water absorption is low and affects the value of water resistance. Phenomenon found in the present study made this study inverse to other studies such as research of Kumar et al. (2020) and Iling et al. (2017). The lower water absorption is caused by the amount of dissolved film. The easier it is for the film to dissolve into water, the faster the process of decomposition (degradation) of the film will be (Asngad, 2018). 


\section{Analysis of Biodegradable Film Cross-Section Morphological Structure (SEM)}

The cross-sectional view of the biodegradable film is shown in Figure 5.

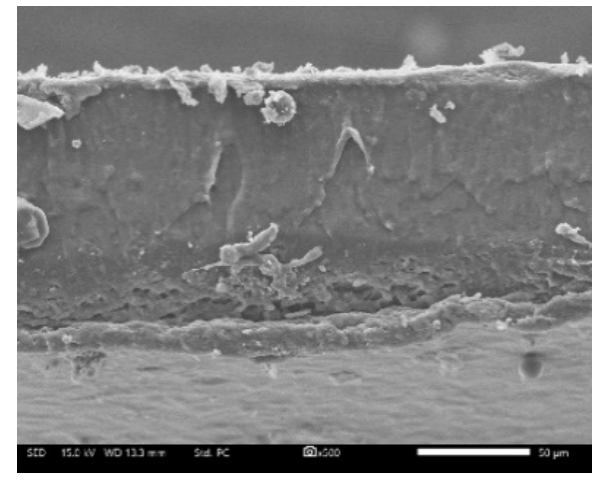

$\mathbf{a}$

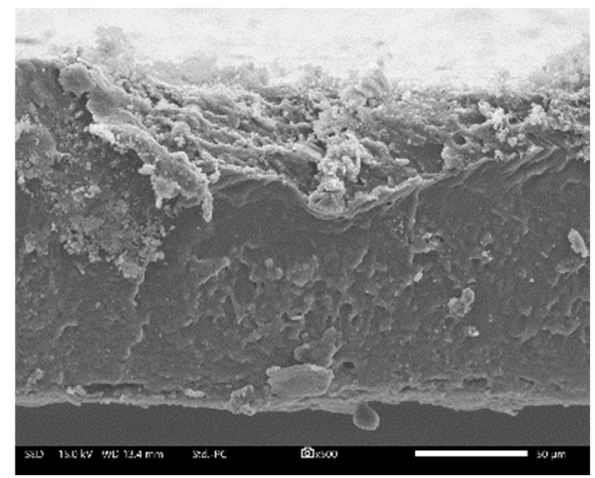

b

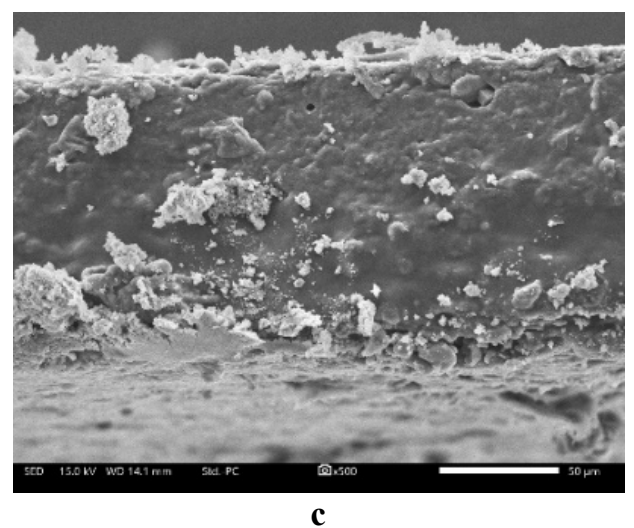

Figure 5. Cross section of biodegradable film with different content of duck bone gelatin: (a) $0 \%$, (b) $5 \%$, (c) $35 \%$

To obtain the observed cross-sections, the biodegradable films were cryogenically cut in liquid nitrogen. The micrographs of biodegradable taro starch films with the addition of content of $0 \%, 5 \%$, and $35 \%$ duck bone gelatin are shown in Figures 5a, 5b, and 5c, respectively. SEM of biodegradable taro starch film (Fig. 5a) shows a relatively rough, dense, and continuous cross-section without pores and cracks, which confirm the solid and homogeneous structure. The micrograph of the biodegradable film with $5 \%$ duck bone gelatin can be seen in the cross-section showing dense and rough results with multiple folds. However, neither duck bone gelatin nor taro starch was seen, meaning that the addition of $5 \%$ duck bone gelatin resulted in a homogeneous and flexible biodegradable film with a compact structure. The micrograph of the biodegradable film with $35 \%$ duck bone gelatin had an uneven, rough, and multiple-fold cross-section (Fig. 5c), which may be due to the flexibility of the gelatin film (Wang et al., 2017). Figure 5c shows a cross-section that is very rough and duck bone gelatin, which is not bound to taro starch, meaning that many hydroxyl groups in duck bone gelatin are bound to free water. This is in accordance with the results of 
the analysis of solubility, water absorption, and water vapor transmission rate. Mixing taro starch with duck bone gelatin aims to improve the internal structure of the taro starch film, where the biodegradable taro starch film with $0 \%$ gelatin shows less roughness and is denser and more compact, which may be caused by its less flexibility (Tongdeesoontorn et al., 2012). Biodegradable films with the addition of duck bone gelatin are a more flexible and will be easily decomposable and environmentally friendly.

\section{Conclusion}

1. Based on the findings, in making biodegradable films based on taro (Xanthosoma saggitifolium) starch and duck bone gelatin, there are some functional groups including $\mathrm{NH}$ at a wavenumber of $3.250 \mathrm{~cm}^{-1}, \mathrm{OH}$ at $2.892 \mathrm{~cm}^{-1}, \mathrm{C}=\mathrm{C}$ at $1.539 \mathrm{~cm}^{-1}, \mathrm{CH}$ at 1.438 $\mathrm{cm}^{-1}$, and $\mathrm{CN}$ at $1.350 \mathrm{~cm}^{-1}$. The biodegradable film functional groups have similarities in the manufacturing materials, namely starch, glycerol, duck bone gelatin, and hydrophilic hydrogen bonds that can facilitate the film degradation.

2. In addition, at a concentration of $35 \%$, duck bone gelatin affects the physical characteristics of the biodegradable film in the form of a water vapor transmission rate of $0.53 \mathrm{~g} / \mathrm{m}^{2}$ hour and a water solubility value of $64.60 \%$. It also affects the value of water absorption (swelling) of $40.47 \%$. The value of water absorption is depend on the number of films that dissolved in water and cause the solubility value to increase.

3. The results of the micrograph of the biodegradable film in the cross-section with SEM analysis show that dense and rough results with many folds, which means that the biodegradable film added with duck bone gelatin gives more flexibility and accelerates degradation.

Acknowledgements. This research was funded by State Polytechnic of Banyuwangi through Research Induk Penelitian (RIP) grant with contract number 2674.37/PL36/PG/2021. The authors also thank to Siti Alfiyah and Rohmatul Iftitah who have helped in completing this research.

\section{References}

[JIS] Japanse Industrial Standar 21770 (1975), General Rules of Plastic Film fod FoodPackaging, Japanesse Standars Association, JSA, Tokyo.

Aripin S., Saing B., Kustiyah E. (2017), Intercalation, Studi Pembuatan Bahan Alternatif Plastik Biodegrdable Dari Pati Ubi jalar Dengan Plasticizer Gliserol dengan metode Melt, Jurnal Teknik Mesin, 6(1), pp. 79-84.

Aritonang D H., Hartiati A., Harsojuwono B A. (2020), Karakteristik Komposit Bioplastik pada Variasi Pati Ubi Talas Belitung (Xanthosoma sagittifolum) dan Karagenan, Jurnal Rekayasa dan Manajamen Agroindustri, 8(3).pp. 348-359.

Aryanti N., Kusumastuti Y., Rahmawati W. (2017), Pati Talas (Colocasia Esculenta (L.) Schott) Sebagai Alternatif Sumber Pati Industri, Jurnal Momentum, 13(1), pp. 46-52, DOI: 0.36499/jim.v13i1.1759

Asngad A., Amella R., Aeni, N. (2018), Pemanfaatan Kombinasi Kulit Kacang Dengan Bonggol Pisang Dan Biji Nangka Untuk Pembuatan Plastik Biodegradable Dengan Penambahan Gliserol, Bioeksperimen: Jurnal Penelitian Biologi, 4(1), pp. 11-19, DOI: 10.23917/bioeksperimen.v4i1.5924

Bani M. D. S. (2019), Variasi Volume Gliserol terhadap Sifat Fisis Plastik Biodegradable Berbahan Dasar Pati Ubi Kayu (Manihot Esculenta Cranz), Jurnal Pendidikan Matematik 
Dan Ilmu Pengetahuan Alam, 7(1), pp. 61-78.

Budianto A., Ayu Dewi F., Johan Vonny S. (2019), Pemanfaataan Pati Kulit Ubi Kayu dan Selulosa Kulit Kacang Tanah Pada Pembuatan Plastik Biodegradable, Sagu, 18(2), pp. 1118.

Chaves Da Silva N. M., Fakhouri F M., Fialho R. L. L., Cabral Albuquerque E. C. D. M. (2018), Starch-Recycled Gelatin Composite Films Produced By Extrusion: Physical And Mechanical Properties, Journal Of Applied Polymer Science, 135(19), pp. 1-9, DOI: 10.1002/App.46254

Darni Y., Chici A., Ismiyati S. (2008), Sintesa Bioplastik dari Pati Pisang dan Gelatin dengan Plasticizer Gliserol, Prosiding Seminar Nasional Sains dan Teknologi-II, UNIL, Lampung, pp. 182-189.

Darni Y., Utami H. (2010), Studi Pembuatan dan Karakteristik Sifat Mekanik dan Hidrofobisitas Bioplastik dari Pati Sorgum, Jurnal Rekayasa Kimia \& Lingkungan, 7(2), pp. 88-93.

Dhirisma F., Sari D. P. (2014), Formulaion of a Membrane-Based Porous Gidrogel Combination of HMPC (Hydroxy Propyl Metyl Celuluse), and Gelatin by using Foamin Gas Method and Determination of Physical-Mechanical Cahartestis, Naskah Publikasi Karya Tulis Ilmiah, 1(1), pp. 1-10.

Gontard N., Guilbert S., Cuq J.L. (1993), Water And Glycerol As Plasticizers Affect Mechanical And Water Vapor Barrier Properties Of An Edible Wheat Gluten Film, Journal Of Food Science, 58(1), 206-211, DOI: 10.1111/J.1365-2621.1993.Tb03246.X

Illing I., MB S. (2017), Uji Ketahanan Air Bioplastik Dari Limbah Ampas Sagu Dengan Penambahan Variasi Konsentrasi Gelatin, Prosiding Seminar Nasional, 3(1), pp. 182-189.

Jagadeesh D., Prashantha K., Mithil Kumar Nayunigari N., Maity A. (2016), Effect of Gelatin Content on Potato Starch Green Composite Films, Indian Journal of Advances in Chemical Science, 4(4), pp. 355-361.

Kong J., S Yu. (2007), Fourier Transform Inrared Spectroscopic Analysis of protein Secondary Structures, Acta Bioch Sin, 39(8), pp. 529-559

Kumar R., Ghoshal G., Goyal M. (2019), Synthesis and functional properties of gelatin/CA-starch composite film: excellent food packaging material, Journal of Food Science and Technology, 56(4),pp. 1-12, DOI: 10.1007/s13197-019-03662-4

Kumar R., Ghoshal G., Goyal M. (2020), Biodegradable composite films / coatings of modified corn starch / gelatin for shelf life improvement of cucumber, Journal of Food Science and Technology, 1(1), pp. 1-11, DOI: 10.1007/s13197-020-04685-y

Miskah S., Ramadianti I. M., Hanif A. F. (2010), Pelarut Dan Waktu Perendaman Pada Pembuatan Gelatin Berbahan Baku Tulang / Kulit Kaki Ayam, Jurnal Teknik Kimia, 1(17), pp. 1-6.

Muin R., Anggraini, D., Malau F. (2017), Karakteristik Fisik dan Antimikroba Edible Film Dari Tepung Tapioka Dengan Penambahan Gliserol Dan Kunyit Putih, Jurnal Teknik Kimia, 23(3), pp. 191-198.

Otoni C. G., Avena-Bustillos RJ, Azeredo HMC, Lorevice MV, Moura MR, Mattoso LHC, Tara H, McHugh TH. (2017), Recent advances on edible films based on fruits and vegetables - a review, Compr Rev Food Sci, 16, pp. 1151-1169, DOI: 10.1111/1541-4337.12281

Puspawati N. M., Widihati I. A. G., Widana I. N. (2017), Komposisi Asam Amino dan Pola Pita Protein Gelatin Halal dari Kulit Ayam Boiler, Jurnal Kimia, 11(1), pp. 36-42.

Putri S Y. (2018), Pengaruh Konsentrasi Plasticizer Sorbitol Terhadap Sifat Fisik dan Mekanik Edible Film Berbasis Protein Sorgum Manis, Fakultas Matematika dan Ilmu Pengetahuan Alam, Departemen Fisika, Institut Pertanian Bogir, Bogor.

Radhiyatullah A., Indriani N., Ginting M. H. S. (2015), Pengaruh Berat Pati Dan Volume Plasticizer Gliserol Terhadap Karakteristik Film Bioplastik Pati Kentang, Jurnal Teknik Kimia USU, 4(3), pp. 35-39, DOI: 10.32734/jtk.v4i3.1479

Rahmawati W., Kusumastuti Y. A., Aryanti N. (2012), Karakterisasi Pati Talas (Colocasia Esculenta (L.) Schott) Sebagai Alternatif Sumber Pati Industri Di Indonesia, Jurnal 
Teknologi Kimia Dan Industri, 1(1), pp. 347-351, Available at: http://ejournals1.undip.ac.id/index.php/jtki

Resalina, Basa, Sri, Mulyadi, D., Yetri, Y. (2013), Pengaruh Penambahan Serbuk Gelatin Terhadap Sifat Mekanik dan Biodegradabilitas Plastik Campuran Polietilen Tereftalat Bekas dan Pati Sagu, Jurnal Fisika Unad, 2(1), pp. 26-32.

Rosseto M., Krein D D., Balbé Naina P., Dettmer A. (2019), Starch - gelatin film as an alternative to the use of plastics in agriculture : a review, Journal of The Science of Food and Agricultur, 99(15), pp. 671-679, DOI: 10.1002/jsfa.9944

Salimah T., Ma'ruf, W F., Romadhon. (2016). Pengaruh Transglutaminase Terhadap Mutu Edible Film Gelatin Kulit Ikan Kakap Putih (Lates calcalifer), Jurnal pengetahuan \& Bioteknologi Hasil Perikanan. 5(1), pp. 49-55.

Santosa H., H Noer, A., Guyana Nurmy L., Handono Sigit Firman D. (2018), Hidrolisa kolagen dalam ceker ayam hasil perendaman dengan asam asetat pada proses pembuatan gelatin, Jurnal Gema Teknologi, 20(1), pp. 32-36.

Satriawan MB., Iling I. (2017), Uji FTIR Bioplastik dari Limbah Ampas Sagu dengan Penambahan Variasi Konsentrasi Gelatin, Jurnal Dinamika, 8(2), pp. 1-13.

Silviana., Brandon P B., Silawanda B A., (2018), Preparation of Cassava Bagasse Starch-Based Biodegradable Film Reinforced with Chicken Feet Gelatin, Citric Acid as Crosslinker, and Glycerol as Plasticizer, Journal Chemistry Indonesia, 4(1), pp. 688-695

Sunardi Susanti Y., Mustikasari, K. (2019), Sintesis Dan Karakterisasi Bioplastik Dari Pati Ubi Nagara Dengan Kaolin Sebagai Penguat, Jurnal Riset Industri Hasil Hutan, 11(2), pp. 65 76, DOI: 10.24111/jrihh.v11i2.5084

Sutra L U., Hermalena, L., Salihat, R, A. (2020), Karakteristik Edible Film Dari Pati Jahe Gajah (Zingiber officinale) dengan Perbandingan Gelatin Ikan Tuna, Journal of Scientech Research and Development, 2(2), pp. 34-44.

Tongdeesoontorn W., Mauer L. J., Wongruong S., Sriburi P., Rachtanapun P. (2012), Mechanical and physical properties of cassava starch-gelatin composite films, International Journal of Polymeric Materials and Polymeric Biomaterials, 61(10), pp. 778-792, DOI: 10.1080/00914037.2011.610049

Udjiana S. S., Hadiantoro S., Syarwani, M., Suharti, P. H. (2019), Pembuatan dan Karakterisasi Plastik Biodegradable dari Umbi Talas (Xanthosoma sagittifolium) dengan Penambahan Filler Kitosan dan Kalsium Silikat, Jurnal Teknik Kimia Dan Lingkungan, 3(1), pp.10-19, DOI: $10.33795 /$ jtkl.v3i1.80

Wang W., Wang K., Xiao J., Liu Y., Zhao Y., Liu A. (2017), Performance of high amylose starchcomposited gelatin films influenced by gelatinization and concentration, International Journal of Biological Macromolecules, 94(1), pp. 258-265, DOI: 10.1016/j.ijbiomac.2016.10.014

Widiyaningsih S., Kartik D., Nurhayati Y T. (2012), Pengaruh Penambahan Sorbitol dan Kalsium karbonat Terhadap Karakteristik dan Sifat Biodegradadable Film Dari Kulit Pisang, Molekul., 7(1), pp. 69-81.

Wijayani Kartika D., Darmanto Y S., Susanto E. (2021), Karakteristik Edible Film Dari Gelatin Kulit Ikan Yang Berbeda, Jurnal Ilmu Dan Teknologi Perikanan, 3(1), pp. 59-64.

Winarti C., Miskiyah, \& Widaningrum. (2012), Teknologi produksi dan aplikasi pengemas Edible Antimikroba berbasis Pati, Jurnal Litbang Pertanian, 31(3), 85093.

Zulferiyani, Marniza, Sari erli N. (2014), Pengaruh Konsentrasi gliserol dan tapioka terhadap karakteristik biodegradable film berbasi rumput laut (Euscheuma cottoni), Jurnal Teknologi Dan Industri Hasil Pertanian, 19(3), pp. 257-270. 